GRASAS Y ACEITES 66 (2)

April-June 2015, e073

ISSN-L: 0017-3495

doi: http://dx.doi.org/10.3989/gya.0695141

\title{
Enzymatic interesterification on the physicochemical properties of Moringa oleifera seed oil blended with palm olein and virgin coconut oil
}

\author{
S. Dollah ${ }^{\mathrm{a}}$, S.M. Abdulkarim ${ }^{\mathrm{a}}$, S.H. Ahmad ${ }^{\mathrm{b}}$, A. Khoramnia ${ }^{\mathrm{a}}$ and H.M. Ghazali ${ }^{\mathrm{a}, \varpi}$ \\ ${ }^{a}$ Department of Food Science, Faculty of Food Science and Technology, Universiti Putra Malaysia, \\ UPM 43400 Serdang, Selangor DE, Malaysia \\ ${ }^{b}$ Department of Crop Science, Faculty of Agriculture, Universiti Putra Malaysia, UPM 43400 Serdang, Selangor DE, Malaysia \\ ${ }^{\square}$ Corresponding author: hasanah@upm.edu.my
}

Submitted: 11 June 2014; Accepted: 23 December 2014

SUMMARY: The enzymatic interesterification (IE) of palm olein (PO) and virgin coconut oil (VCO) with the high oleic acid (86\%) Moringa oleifera seed oil (MoO) could yield a good source of oleic acid fat stock that may contain desirable nutritional and physical properties. Lipozyme RMIM resulted in different functionalities for the $\mathrm{MoO} / \mathrm{PO}$ and $\mathrm{MoO} / \mathrm{VCO}$ blends due to inherent changes in triacylglycerol (TAG) compositions which, in turn, led to different trends in DSC thermograms and solid fat contents (SFC). The enzymatic IE of MoO/VCO increased $\mathrm{U}_{2} \mathrm{~S}$ and $\mathrm{S}_{2} \mathrm{U}$ (up to $20 \%$ medium and long chain, MLCT) while it decreased $\mathrm{U}_{3}$ (triunsaturated) and $\mathrm{S}_{3}$ (trisaturated) TAGs. The IE of the MoO/PO blends increased $\mathrm{U}_{2} \mathrm{~S}$ and $\mathrm{S}_{3}$ (MMP, myristic, myristic, palmitic) and decreased $\mathrm{S}_{2} \mathrm{U}$, resulting in a lowering of melting points and SFC for MoO/VCO, while showing an increase in them for MoO/PO. A 2.55\% increase in S3 after $24 \mathrm{~h} \mathrm{MoO} / \mathrm{PO} 30: 70 \mathrm{IE}$ revealed a 6.5\% harder oil at $10{ }^{\circ} \mathrm{C}$ which may imply a wider application compared to the original liquid oils. Novel MLCTs with improved nutritional and physical properties were generated in the $\mathrm{MoO} / \mathrm{VCO}$ blends after IE due to the incorporation of oleic acid and medium chain fatty acids. MoO/PO 50:50 and 70:30 w/w after $12 \mathrm{~h} \mathrm{IE} \mathrm{and} \mathrm{MoO/VCO} \mathrm{30:70}$ are suitable for incorporation into the fat phase in ice-cream formulations while, the spreadability and plasticity of MoO/VCO 70:30 improved at low temperatures. Both interesterified blends could be used as high oleic acid frying oils.

KEYWORDS: Interesterification; Lipozyme RMIM; Moringa oleifera seed oil; Physicochemical properties; Structured lipids

RESUMEN: Interesterificación enzimática sobre las propiedades físico-químicas de las mezclas de aceites de semillas de Moringa oleifera con oleína de palma y aceite de coco virgen. La interesterificación enzimática (IE) de la oleína de palma (PO), aceite de coco virgen (VCO) con alto contenido en ácido oleico (86\%) y aceites de semilla de Moringa oleifera (MOO) podría ser una buena fuente de ácido oleico con propiedades nutricionales y físicas deseables. La lipozyme RMIM produce diferentes funcionalidades para las mezclas $\mathrm{MoO} / \mathrm{PO}$ y $\mathrm{MoO} /$ VCO debido a los cambios inherentes en la composición de triacilgliceroles (TAG) que, a su vez, dieron lugar a diferentes perfiles en los termogramas de DSC y en los contenidos de grasa sólida (SFC). La IE de MoO/VCO aumentó los TAGs, $\mathrm{U}_{2} \mathrm{~S}$ y $\mathrm{S}_{2} \mathrm{U}$ (hasta un $20 \%$ de cadena media y larga, MLCT), mientras que disminuyó los TAGs triinsaturados $\left(\mathrm{U}_{3}\right)$ y trisaturados $\left(\mathrm{S}_{3}\right)$. La IE de mezclas MoO/PO, aumentó los TAGs $\mathrm{U}_{2} \mathrm{~S}$ y $\mathrm{S}_{3}(\mathrm{MMP}$, mirístico, mirístico, palmítico) y disminuyó $\mathrm{S}_{2} \mathrm{U}$, lo que da lugar a una reducción del punto de fusión y de SFC para el $\mathrm{MoO} / \mathrm{VCO}$ mientras que estos parámetros aumentan para $\mathrm{MoO} / \mathrm{PO}$. El aumento de un $2.55 \%$ en $\mathrm{S}_{3}$ después de $24 \mathrm{~h}$ de IE de $\mathrm{MoO} / \mathrm{PO} 30: 70$ da lugar a aceites $6,5 \%$ más duros a $10^{\circ} \mathrm{C}$, que pueden tener unas aplicaciones más amplias en comparación con los aceites líquidos originales. Nuevos MLCTs con mejores propiedades 
nutricionales y físicas se generaron con las mezclas $\mathrm{MoO} / \mathrm{VCO}$ tras IE debido a la incorporación de ácido oleico y ácidos grasos de cadena media. MoO/PO 50:50 y 70:30 w/w después de 12 h de IE y MoO/VCO 30:70 son adecuados para su incorporación como grasa en las formulaciones de helados, mientras que la untabilidad y plasticidad de MoO/VCO 70:30 mejoró a bajas temperaturas. Ambas mezclas interesterificadas podrían ser utilizados como aceites alto oleico para fritura.

PALABRAS CLAVE: Aceites de semillas de Moringa oleifera; Interesterificación; Lípidos estructurados; Lipozyme RMIM; Propiedades fisicoquímicas

Citation/Cómo citar este artículo: Dollah S, Abdulkarim SM, Ahmad SH, Khoramnia A, Ghazali HM. 2015. Enzymatic interesterification on the physicochemical properties of Moringa oleifera seed oil blended with palm olein and virgin coconut oil. Grasas Aceites 66 (2): e073. doi: http://dx.doi.org/10.3989/gya.0695141.

Copyright: (C) 2015 CSIC. This is an open-access article distributed under the terms of the Creative Commons Attribution-Non Commercial (by-nc) Spain 3.0 Licence.

\section{INTRODUCTION}

Several processes are used to modify and improve the properties of vegetable oils and therefore, the versatility to widen their commercial applications. Lipase-catalyzed interesterification has been extensively studied for this purpose (Liew et al., 2001; Palla et al., 2012). Among commercially available lipase preparations, immobilized Lipozyme RMIM (from Rhizomucor miehei) has been extensively used for the production of specifically structured lipids (Chen et al., 2007). Structured lipids (SLs) are defined as triacylglycerols (TAGs) that have been modified by the incorporation of new fatty acids, restructured to change the positions of FA, or synthesized to yield novel TAGs (Xuebing et al., 2002), aimed at obtaining some desirable nutritional or physicochemical properties (da Silva et al., 2010).

Dietary consumption of high oleic acid oils has been reported to have physiological benefits such as lowering serum cholesterol levels, suppressing certain types of cancer, enhancing liver function, and reducing the effects of aging and coronary disease (Carluccio et al., 2007). These nutritional advantages are attributed to the elevated level of monounsaturated fatty acids (MUFA) and reduced saturate contents (Gerhard et al., 2004). According to Riveros et al. (2010), MUFA also contributes to a longer shelf life of products due to its high resistance against oxidation and rancidity at ambient storage and at high temperatures (Warner et al., 1997) compared to polyunsaturated fatty acids (PUFA). Some high-oleic oils such as olive could be used for frying (Abdulkarim, et al., 2007a); however, its high cost restricts its usage on a major scale. Therefore, the use of more stable frying oils of comparatively low price would be desirable. Among newer sources of edible oils, Moringa oleifera seed oil (MoO) is of interest and may play a major role in human nutrition and health, because of its resemblance to olive oil (Abdulkarim et al., 2005; Ramachandran et al., 1980).

With a high amount of MUFA (81.73\%) and low PUFA $(0.71 \%), \mathrm{MoO}$ represents an alternative source of superior oil with high stability and good characteristics concerning the prevention of cholesterol and heart disease (Abdulkarim et al., 2005; Ramachandran et al., 1980) and a fatty acid (FA) composition resembling olive oil (Abdulkarim et al., 2005; Ramachandran et al., 1980). Moringa oleifera is a tree growing rapidly even in poor soil and is little affected by drought (Tsaknis and Lalas, 2002) and can be easily grown in poor third world countries. The production of useful SLs from this oil interesterified with other vegetable oils could be of economic and nutritional benefits to the native population of the areas where the tree is cultivated. Two vegetable oils, palm olein (PO) and Virgin coconut oil (VCO) have been selected to be interesterified with $\mathrm{MoO}$ in order to evaluate the effect of lipase on their characteristics.

PO, which is the most commonly used oil for frying foods in the Southeast Asia region (Bansal et al., 2010), is a liquid fraction of palm oil and contains a high proportion of saturated fatty acids that contributes to related health disorders. Because the eating habits of most Malaysian people are based on deep fried foods, oxidative-resistant low saturated oils are needed. It has been previously reported that more than $90 \%$ of the lipids in fried food came from the frying oil (Pérez-Camino et al., 1991) due to the interactions between food and frying oil (Bansal et al., 2010). Abdulkarim et al. (2007a) and Tsaknis and Lalas (2002) reported that $\mathrm{MoO}$ has greater frying stability over other conventional frying oils such as canola oil, soybean oil and palm olein. This requirement can be met through the interesterification process of $\mathrm{PO}$ with unsaturated oils like MoO.

$\mathrm{VCO}$, as a main source of medium-chain triacylglycerol (MCT), has been used for years to treat patients with malabsorption of fat problems and provide instant energy to athletes (Marina et al., 2009b). However, as MCT contain solely medium chain fatty acids (MCFA), it lacks essential fatty acids such as oleic acid. MCT is also unsuitable for cooking purposes such as frying as it has a lower 
smoke point and high foaming tendency (Lee et al., 2012; Matsuo et al., 2001). Hence, long chain fatty acids (LCFA) should be incorporated into the MCT molecules to overcome these weaknesses. This will lead to the development of a new type of structured lipids, called medium-and long-chain triacylglycerol (MLCT). This can either be produced via a lipase-catalyzed reaction of acidolysis, esterification, or interesterification (Koh et al., 2010; Lee et al., 2012). MLCT-based oil blends can be used as healthy functional oils for daily consumption such as in salad dressing and for frying (Koh et al., 2010). Thus, the objective of this study was to investigate the physical and chemical properties of enzymatically interesterified $\mathrm{MoO} / \mathrm{PO}$ and $\mathrm{MoO} / \mathrm{VCO}$ blends and to predict the food applications of the resulting products.

\section{MATERIALS AND METHODS}

Brown, mature $M$. oleifera pods were collected in the Serdang area in Selangor, Malaysia. The seeds were removed from the pods and crushed gently to obtain the seed kernels which were then sorted to remove any misshapen seeds. Well-formed seed kernels were dried in a convection oven at $60^{\circ} \mathrm{C}$ for $12 \mathrm{~h}$. PO was purchased from Lam Soon Edible Oil Sdn. Bhd., Malaysia, while VCO was produced from fresh coconut milk purchased from a local wet market. All solvents and chemicals used in this study were either of analytical or HPLC grade and purchased from BDH Laboratories (Pool, England), Merck (Darmstadt, Germany) and Sigma Aldrich Inch. (St. Louis, California, USA). Individual FA methyl ester standards of caprylic (C8:0), capric (C10:0), lauric (C12:0), myristic (C14:0), palmitic (C16:0), palmitoleic (C16:1), stearic (C18:0), oleic (C18:1), linoleic (18:2), arachidic (C20:0), eicosenoic (C20:1), behenic (C22:0) and lignoceric (C24:0) acids, approximately $99 \%$ pure, were purchased from Supelco (Sigma-Aldrich Tokyo, Japan). Immobilized Lipozyme RMIM (Rhizomucor miehei) purchased from Novozymes A/S, Bagsvaerd, Denmark, was used for the IE reaction in a solvent-free system.

\subsection{Extraction of $\mathrm{MoO}$}

$\mathrm{MoO}$ was extracted from dried M. oleifera kernels that had been ground into a fine powder using a Waring blender Model 32BL 80 (Dinamic Corpration of America, New Hartford, Connecticut, USA). The ground kernel (500 g) was placed in a cellulose filter paper (Whatman No. 1) cone and the oil was extracted using light petroleum ether (b.p $40-60{ }^{\circ} \mathrm{C}$ ) in a $5 \mathrm{~L}$ Soxhlet extractor for 8 hours (AOAC, 1984). The solvent was then evaporated off using a rotary evaporator Model N-1 (Eyela, Tokyo Rikakikal Co., Ltd., Japan) and the recovered oil was heated in a convection oven at $60{ }^{\circ} \mathrm{C}$ for 1 hour to remove residual solvent. The oil was then flushed with $99.9 \%$ nitrogen and stored at $-20{ }^{\circ} \mathrm{C}$ until further use (Abdulkarim et al., 2005). The crude oil was used without further refining.

\subsection{Production of VCO}

VCO was produced using the natural fermentation method described by Bawalan and Chapman (2006). One kilogram of fresh coconut milk was placed in a $2 \mathrm{~L}$ beaker, covered with aluminum foil and left standing at room temperature $\left(25-27^{\circ} \mathrm{C}\right)$ for 24 hours for natural fermentation to take place. The upper layer (oil layer) was then filtered through a filter paper (Fisher QC100, Fisher Scientific, Leicestershire, UK) and heated at $60^{\circ} \mathrm{C}$ in a convection oven overnight to remove extra moisture in the oil. The oil was kept in $-20^{\circ} \mathrm{C}$ for analysis.

\subsection{Interesterification reaction}

Sixty grams $(60 \mathrm{~g})$ of melted $M$. oleifera seed oil/palm olein (MoO/PO) and M. oleifera seed oil/ virgin coconut oil $(\mathrm{MoO} / \mathrm{VCO})$ blends at ratios of 70:30, 50:50 and 30:70 (w/w), each dissolved separately in $100 \mathrm{~mL}$ of water-saturated n-hexane, were placed in $250 \mathrm{~mL}$ conical flasks. Lipozyme RMIM $(10 \% \mathrm{w} / \mathrm{w}$ of oil mixture) was then added to initiate catalysis. The reaction mixtures were agitated at $60^{\circ} \mathrm{C}$ at $200 \mathrm{rpm}$ for $0,3,6,12$ and $24 \mathrm{~h}$. The blend ratios were selected based on preliminary experiments that show desired changes after blending and IE. The reaction mixture at $0 \mathrm{~h}$ acted as the control. After the reaction, each oil mixture was filtered through a Whatman No. 1 filter paper to remove the enzyme and the oil mixtures were kept at $-20{ }^{\circ} \mathrm{C}$ for further analysis. The reaction was carried out in duplicate. The stored mixtures were thawed at room temperature and then heated at $60^{\circ} \mathrm{C}$ for $30 \mathrm{~min}$ to ensure complete melting before analysis.

\subsection{Removal of free fatty acid}

Free fatty acids (FFAs) were removed from the reacted oil using the method described by Long et al. (2003). The reacted oil (30 g) was placed in a $250 \mathrm{~mL}$ conical flask and $50 \mathrm{~mL}$ of acetone: ethanol $(1: 1 \mathrm{v} / \mathrm{v})$ were added and mixed. The mixture was then titrated against $0.1 \mathrm{~N} \mathrm{NaOH}$ to a phenolphthalein end-point. The titrated sample was diluted with $10 \mathrm{~mL}$ of boiling distilled water and transferred to a $250 \mathrm{~mL}$ separating funnel. The mixture was shaken and allowed to settle for several minutes. The aqueous phase which contained the FFA, was separated from the organic phase and discarded. The organic phase was then dried at $60{ }^{\circ} \mathrm{C}$ overnight. 


\subsection{Triacylglycerol profile}

The triacylglyceride (TAG) profiles of the oil samples were obtained by injecting $10 \mu \mathrm{L}$ of oil samples $(10 \%$ in acetone, v/v) into a reversed-phase high performance liquid chromatograph (HPLC) comprising a Waters Alliance HPLC (Waters Corporation, Milford, Massachusetts, USA) equipped with a separation module (Waters Model 2695), an auto-injector and a refractive index detector (Waters Model 2414). The TAG were separated using a commercially packed RP-18 column $(250 \times 4 \mathrm{~mm})$ with particle size $5 \mathrm{~mm}$ (Merck, Darmstadt, Germany) held in a column oven set at $35^{\circ} \mathrm{C}$. Elution of TAG from the column was achieved using a mixture of acetone/ acetonitrile (63.5:36.5) as the mobile phase at a flow rate of $1 \mathrm{~mL} \cdot \mathrm{min}^{-1}$. The total run time was $100 \mathrm{~min}$ and TAG peaks were identified based on the retention time of available TAG standards and the results of Chen et al. (2007) and Marina et al. (2009a). Peak areas produced by the data integrator (EmpowerPro Version 2002, Waters Corporation, Milford, Massachusetts, USA) were used to quantify the components based on relative percentages.

\subsection{Thermal properties}

The thermal properties of the oil samples were investigated by differential scanning calorimetry (DSC) using a Perkin-Elmer Diamond DSC (Shelton, Connecticut, USA) based on the procedure described by Abdulkarim et al. (2005). The instrument was calibrated using indium and zinc. The purge gas used was $99.9 \%$ nitrogen with a flow rate of $100 \mathrm{~mL} \cdot \mathrm{min}^{-1}$ and a pressure of 20 psi. Samples (5-8 $\mathrm{mg}$ that had been completely melted at $60{ }^{\circ} \mathrm{C}$ ) were sealed in aluminum volatile DSC pans and placed in the instrument's sample chamber. An empty DSC pan was used as the reference. The sample chamber was heated to $70{ }^{\circ} \mathrm{C}$ and held for $2 \mathrm{~min}$ to erase crystal memory in the oil. It was then cooled to $-60{ }^{\circ} \mathrm{C}$ at the rate of $10^{\circ} \mathrm{C} \cdot \mathrm{min}^{-1}$, and held at $-60{ }^{\circ} \mathrm{C}$ isothermally for 2 min and heated from $-60^{\circ} \mathrm{C}$ to $70^{\circ} \mathrm{C}$ at the rate of $10^{\circ} \mathrm{C} /$ minute. The heating and cooling thermograms were recorded and the values for onset, peak and end set temperatures tabulated. The onset temperature indicates the temperature at which the melting process starts and the end set temperature indicates the complete melting temperature of the oil.

\subsection{Prediction of solid fat content}

The solid fat contents (SFC) of all samples at different temperatures were calculated from their thermal profiles according to Adhikari et al. (2010), as obtained above. Each DSC melting thermogram was divided into different temperature sectors $(0,5,10$, $15,20,25,30,35,40,45,50$ and $55^{\circ} \mathrm{C}$ ) and the total crystallization energy $(\mathrm{J} / \mathrm{g})$ at each temperature was then converted into percentage $(\%)$ fat based on the following equation:

$$
(\%) \text { Fat }=[\operatorname{Partial}(\mathrm{J} / \mathrm{G}) / \operatorname{Total}(\mathrm{J} / \mathrm{G})] \times[100]
$$

\subsection{Statistical analysis}

A statistical analysis was carried out using MINITAB 14 (Minitab Inc., State College, PA, USA) by subjecting all the data obtained to a univariate analysis of variance (ANOVA) to determine the significant differences among samples, monitored by Tukey's pairwise test, and significance was defined at $p<0.05$. All measurements were carried out in triplicate and reported as the mean and standard deviation of independent trials.

\section{RESULTS AND DISCUSSION}

\subsection{Degree of oil hydrolysis following interesterification}

Interesterification (IE) requires the hydrolysis of oil by lipase in order to produce free fatty acids (FFAs) and a mixture of mono- and diacylglycerols. These products of hydrolysis will then be synthesized to generate more of either existing or new kinds of TAG. Since not all FFAs participated in the IE process, they may accumulate in the reaction mixture. The original amount of FFA in extracted $\mathrm{MoO}$ and VCO found to be $0.56 \%$ and $0.23 \%$ respectively where no FFA was recorded in refined bleached deodorized (RBD) PO. In this study, after the reaction, the FFA contents were found to be increased significantly $(\mathrm{p}<0.05)$ with the time of reaction compared to the unreacted blends for both $\mathrm{MoO} / \mathrm{PO}$ and $\mathrm{MoO} / \mathrm{VCO}$ in which the highest FFA levels were produced after $24 \mathrm{~h}$ reaction time. Post-IE FFA levels for $\mathrm{MoO} / \mathrm{PO}$ blends ranged between 1.85 and $2.14 \%$, whereas the control values (pre-IE) ranged from 0.37 to $0.60 \%$. For MoO/VCO blends, post-IE and pre-IE values of FFA content ranged from 1.75 to $3.24 \%$ and 0.23 to $0.42 \%$, respectively. Prior to the analysis of other physicochemical properties, as many FFAs as possible were removed by solventsolvent fractionation as they might act as an interference. The FFA levels of interesterified $\mathrm{MoO} / \mathrm{PO}$ and $\mathrm{MoO} / \mathrm{VCO}$ blends after their removal were between 0.15 and $0.18 \%$ and 0.12 and $0.18 \%$, respectively.

\subsection{Effect of enzymatic interesterification on triacylglyceride profile}

Figure 1 shows the triacylglyceride (TAG) profiles of $\mathrm{MoO} / \mathrm{PO}$ and $\mathrm{MoO} / \mathrm{VCO}$ blends at the ratio of 50:50 w/w and their interesterified blends at zero (control) and $24 \mathrm{~h}$ reaction time. After Lypozyme RMIM IE, several TAG peaks increased in height indicating synthesis, while others decreased 

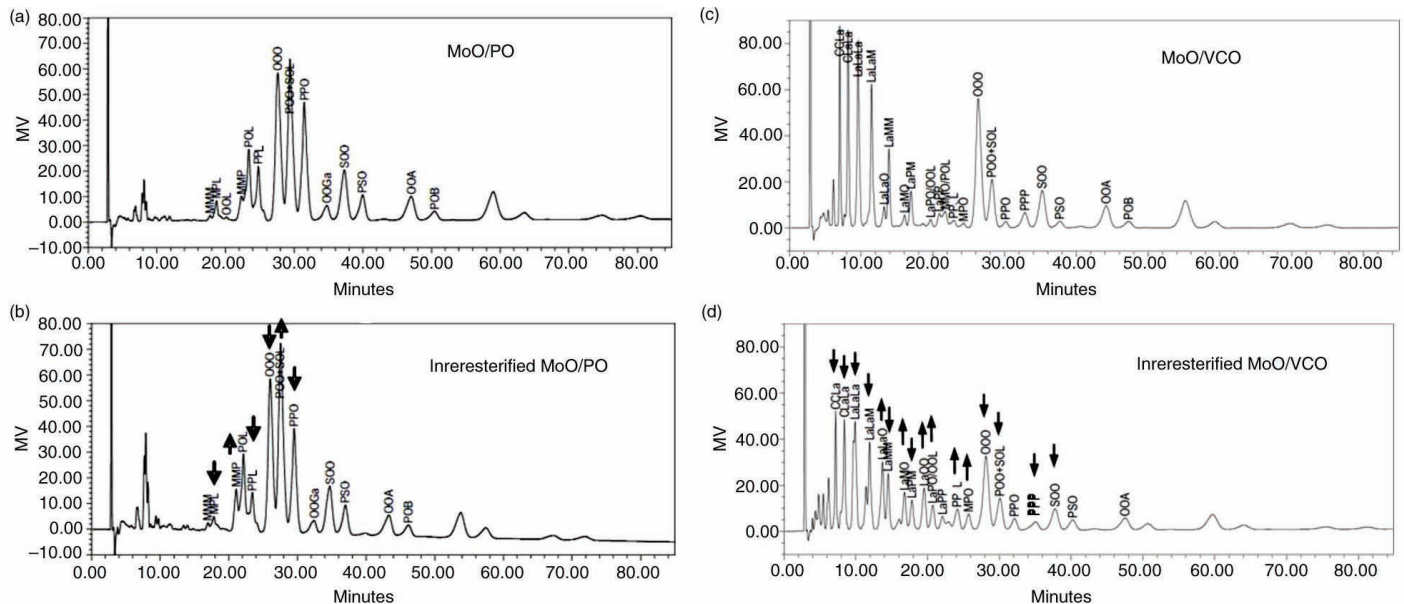

FIgure 1. Triacylglyceride profiles of non-interesterified MoO/PO (a), MoO/VCO (c) blends and 24 h, 50:50 w/w, Lipozyme RMIM interesterified $\mathrm{MoO} / \mathrm{PO}$ (b), MoO/VCO (d) blends. $\uparrow$ arrows depict increases while $\downarrow$ arrows depict decreases in TAG concentrations.

Abbreviations: M: myristic acid; P: palmitic acid; S: stearic acid; O: oleic acid; L: linoleic acid; C: capric acid; La: lauric acid.

indicating hydrolysis. By comparing with the control (pre-IE), TAG groups (S3, S2U, U2S and U3, where $\mathrm{S}$ and $\mathrm{U}$ represent saturated and unsaturated fatty acids, respectively) of $\mathrm{MoO} / \mathrm{PO}$ and $\mathrm{MoO} / \mathrm{VCO}$ interesterified blends shown in Table 1 provide evidence of changes in the TAG composition based on the degree of unsaturation.

As complete identification of TAG in $\mathrm{MoO} / \mathrm{PO}$ is limited by the unavailability of standards, only relative changes in the concentrations of MMP, POO+POL, MPL, PPL, OOO and PPO (where M, $\mathrm{P}, \mathrm{O}$ and $\mathrm{L}$ indicate myristic, palmitic, oleic and linoleic acids respectively) were tracked. POO and POL were quantified together due to both having the same retention time under the conditions used in the analysis. The interesterified $(24 \mathrm{~h}) \mathrm{MoO} /$ $\mathrm{PO}$ blends showed major increases in $\mathrm{POO}+\mathrm{SOL}$ (U2S) due to the incorporation of oleic acid from $\mathrm{MoO}$ fatty acids. The levels of $\mathrm{U} 2 \mathrm{~S}$ were found to be $30.57 \%, 25.88 \%$ and $22.48 \%$ with enhancement values of $4.51 \%, 3.66 \%$ and $4.34 \%$ for $30: 70,50: 50$ and $70: 30 \mathrm{w} / \mathrm{w}$, respectively. On the other hand, PPO and PPL levels (S2U) decreased considerably with the values of $2.58 \%$ and $1.59 \%$ in $50: 50 \mathrm{w} / \mathrm{w}$ respectively and less saturated TAGs (U2S) were increased. As a result, a gradual increase in U2S and a decrease in S2U were observed in all blend ratios. Palla et al. (2012) reported that an increase occurred in U2S after sunflower oil was reacted with palmitic-stearic acid mixtures using Lipozyme RMIM as a result of a reaction between U3 and S2U groups. Debnath et al. (2011) also reported on the increase of U2S and the decrease in S2U in interesterified $\mathrm{PO}$ and rice bran oil blends compared to the unreacted PO. As shown in Table 1, the level of U3 TAGs (OOO) remained unchanged except in $50: 50 \mathrm{w} / \mathrm{w}$ with a $1.23 \%$ decrease (from $21.55 \%$ to $20.32 \%$ ) however, S3 TAGs were increased in all interesterified $\mathrm{MoO} / \mathrm{PO}$ binary blends with the values of $1.13 \%$ in $70: 30,1.83 \%$ in $50: 50$ and $2.55 \%$ in 30:70. A similar observation was reported by Ghazali et al. (1995a) where an increase of S3 in all interesterified PO which was catalyszd using microbial lipases from different sources. The $\mathrm{MoO} / \mathrm{PO}$ blends that showed the highest increase $\mathrm{s}$ in U2S after being interesterified by Lipozyme RMIM for $24 \mathrm{~h}$ were 30:70 and 50:50 ratios. The decrease in the level of S2U and increase in the level of U2S are desired (da Silva et al., 2010; Ribeiro et al., 2009) as such; an increase in TAG containing unsaturated fatty acids may contribute positively to the stability to the oil as well as to its health benefits. Unexpectedly, S3 enhancement resulted in interesterified MoO/PO, which is also desirable in this study, as MMP (myristic myristic palmitic) would be the representative of this type of TAG group (Figure 1a). MMP, which is a medium-mediumlong chain (MML) TAG, is generally called MLCT (medium long chain TAG) and when considered as a structured lipid (SL), would be a beneficial and nutritional fat (Lee et al., 2012) which was generated due to the rearrangements of the TAG occurring after IE .

The same trend with $\mathrm{MoO} / \mathrm{VCO}$ blends following Lipozyme RMIM IE occurred in the case of U2S and S2U TAGs. As shown in Table 1, as IE progressed, the level of U2S increased while, S2U decreased gradually in all ratios of the MoO/VCO blends. However, the trend for changes in U3 (OOO) was completely different from the $\mathrm{MoO} / \mathrm{PO}$ results. The rate of U3 hydrolysis was much lower $(0-1.23 \%)$ in $\mathrm{MoO} / \mathrm{PO}$ IE compared to $\mathrm{MoO} / \mathrm{VCO}$ IE $(3.15-6.73 \%)$ where OOO showed the greatest decrease in concentration over the time of IE (Table 1). The highest amount of TAG hydrolysis (OOO decreased $6.73 \%$ ) occurred after $24 \mathrm{~h}$ IE of 


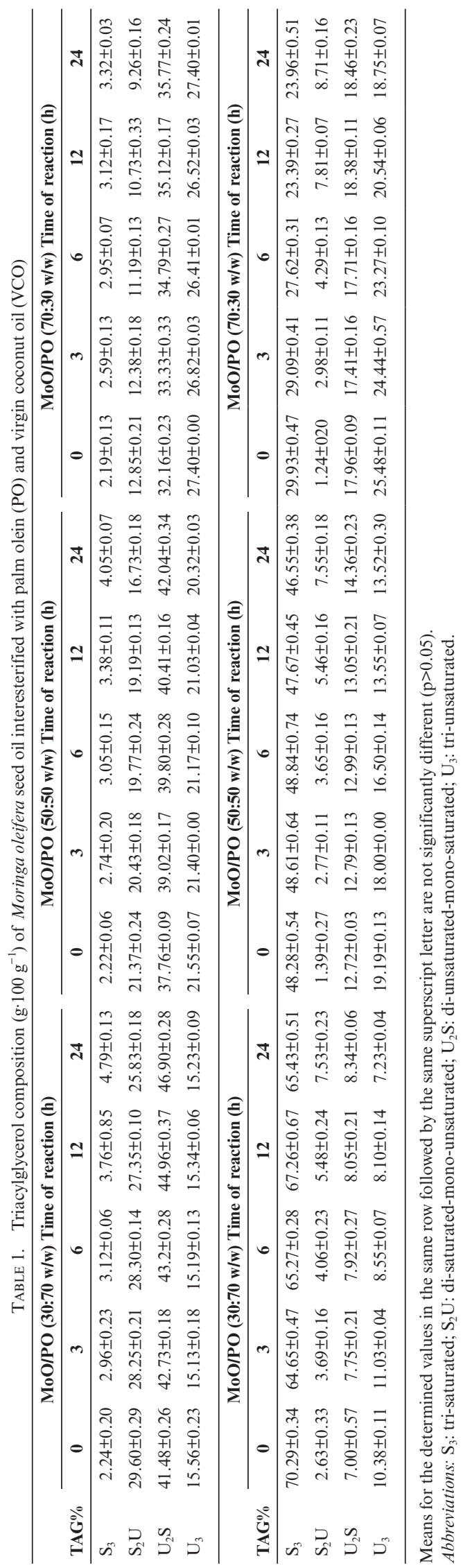

$\mathrm{MoO} / \mathrm{VCO} 70: 30 \mathrm{w} / \mathrm{w}$, while the lowest amount (no change in $\mathrm{OOO}$ value) was detected for the $24 \mathrm{~h}$ interesterified $\mathrm{MoO} / \mathrm{PO}$ 70:30 w/w. in the case of $\mathrm{MoO} / \mathrm{VCO} \mathrm{IE}$, other TAGs that showed corresponding decreases proportional to the reaction time belong to S3 TAGs consisting of CCLa, CLaLa, LaLaLa, LaLaM, and LaPM.

As shown in Table 2, the function of Lipozyme RMIM on MoO/VCO IE resulted in the increase in MLCT species ( $\mathrm{LaLaO}$, LaMO, LaPM and $\mathrm{LaPO}$ ) concentration as well as the synthesis of a new TAG species ( $\mathrm{LaOO})$. In fact, the major MLCT group generated following IE was MLL (medium-long-long) comprising $\mathrm{LaOO}$ in all $\mathrm{MoO} / \mathrm{VCO}$ ratios with a maximum value of $5.43 \%$ in $24 \mathrm{~h}$ interesterified $\mathrm{MoO} / \mathrm{VCO} 70: 30 \mathrm{w} / \mathrm{w}$ (Table 2 ). The most noteworthy increase in TAG concentration was observed for MML (medium-mediumlong chain), the TAG group comprising $\mathrm{LaLaO}$ and LaMO in all MoO/VCO ratios (Table 2). The total amount of generated MLCT with incorporated oleic acid ( $\mathrm{LaLaO}, \mathrm{LaMO}, \mathrm{LaPO}$ and $\mathrm{LaOO}$ ) was maximized in $24 \mathrm{~h}$ interesterified $\mathrm{MoO} / \mathrm{VCO}$ 50:50 with the value of $17.86 \%$. It has been well established that substrate ratio is an important parameter to obtain the desirable yield in IE (Fomuso et al., 1998).

In this study, IE resulted in the increase and synthesis of new TAGs, which was revealed by the emergence of several lower molecular weight TAGs, namely MLCT. The first commercially available MLCT sold in the market by Nisshin Ollio Ltd. Group, Ltd, uses the enzymatic IE process for its production involving coconut or palm kernel oil and an edible vegetable oil (rapeseed, cottonseed and soybean oil) (Lee et al., 2012). Khatoon et al. (2005) reported on interesterified palm stearin with coconut oil, where LaLaLa decreased tremendously while that of $\mathrm{LaLaO}$ and $\mathrm{LaOO}$ experienced major increases. In other studies, the incorporation of medium chain saturated FAs occurred in safflower oil (Utsugi et al., 2009) and anhydrous milk fat (Liew et al., 2001). From the health benefit point of view, MLCT not only can provide us with nutritional properties from the essential fatty acids incorporated, but most importantly it can also help to reduce body weight and body fat accumulation in the body (Lee et al., 2012).

During IE, Lipozyme RMIM catalyzes the cleavage of FAs from the glycerol backbone of some TAG species at the 1, 3 position (those that decreased in concentration after the reaction) and re-esterifies randomly at the free hydroxyl positions on the glycerol backbone of the existing acylglycerols. The difference in lipozyme RMIM functionality toward PO and VCO interesterified blends with $\mathrm{MoO}$ could be due to the processing methods undergone. As mentioned by O'Brien (2003), the PO 
TABLE 2. Relative percentage of medium and long chain triacylglycerol (MLCT) in the control and interesterified $\mathrm{MoO} / \mathrm{VCO}$ blends

\begin{tabular}{|c|c|c|c|c|c|c|}
\hline \multirow[b]{2}{*}{ TAG } & \multirow{2}{*}{$\begin{array}{l}\text { Type of } \\
\text { MLCT }\end{array}$} & \multicolumn{5}{|c|}{ Time of reaction (h) } \\
\hline & & $\mathbf{0}$ & 3 & 6 & 12 & 24 \\
\hline \multicolumn{7}{|l|}{$30: 70$} \\
\hline $\mathrm{LaLaO}$ & MML & $2.63 \pm 0.25^{\mathrm{a}}$ & $3.69 \pm 0.13^{\mathrm{b}}$ & $4.29 \pm 0.13^{\mathrm{b}}$ & $5.48 \pm 0.11^{\mathrm{c}}$ & $6.99 \pm 0.13^{\mathrm{d}}$ \\
\hline LaMO & MML & $1.05 \pm 0.07^{\mathrm{a}}$ & $1.92 \pm 0.03^{\mathrm{b}}$ & $2.87 \pm 0.10^{\mathrm{c}}$ & $3.49 \pm 0.13^{\mathrm{d}}$ & $4.17 \pm 0.10^{\mathrm{e}}$ \\
\hline LaPM & MLM & $3.32 \pm 0.03^{\mathrm{a}}$ & $3.39 \pm 0.13^{\mathrm{a}}$ & $4.58 \pm 0.11^{\mathrm{b}}$ & $4.50 \pm 0.28^{\mathrm{b}}$ & $4.14 \pm 0.06^{\mathrm{b}}$ \\
\hline $\mathrm{LaOO}$ & MLL & $0.15 \pm 0.07^{\mathrm{a}}$ & $0.86 \pm 0.08^{\mathrm{b}}$ & $2.49 \pm 0.13^{\mathrm{c}}$ & $2.67 \pm 0.10^{\mathrm{c}}$ & $3.31 \pm 0.01^{\mathrm{d}}$ \\
\hline $\mathrm{LaPO}$ & MLL & $0.40 \pm 0.00^{\mathrm{a}}$ & $1.08 \pm 0.11^{\mathrm{a}}$ & $2.29 \pm 0.13^{\mathrm{c}}$ & $1.92 \pm 0.03^{\mathrm{b}}$ & $1.33 \pm 0.08^{\mathrm{d}}$ \\
\hline \multicolumn{7}{|l|}{ 50:50 } \\
\hline $\mathrm{LaLaO}$ & MML & $1.39 \pm 0.13^{\mathrm{a}}$ & $2.77 \pm 0.10^{\mathrm{b}}$ & $3.65 \pm 0.07^{\mathrm{c}}$ & $5.46 \pm 0.08^{\mathrm{d}}$ & $7.55 \pm 0.07^{\mathrm{e}}$ \\
\hline LaMO & MML & $0.70 \pm 0.03^{\mathrm{a}}$ & $1.01 \pm 0.11^{\mathrm{b}}$ & $1.46 \pm 0.06^{\mathrm{c}}$ & $3.15 \pm 0.08^{\mathrm{d}}$ & $3.98 \pm 0.07^{\mathrm{e}}$ \\
\hline LaPM & MLM & $2.33 \pm 0.01^{\mathrm{a}}$ & $2.25 \pm 0.04^{\mathrm{b}}$ & $2.26 \pm 0.01^{\mathrm{b}}$ & $3.53 \pm 0.20^{\mathrm{c}}$ & $3.25 \pm 0.06^{\mathrm{c}}$ \\
\hline $\mathrm{LaOO}$ & MLL & $0.00 \pm 0.04^{\mathrm{a}}$ & $0.97 \pm 0.06^{\mathrm{b}}$ & $1.70 \pm 0.13^{\mathrm{c}}$ & $3.87 \pm 0.11^{\mathrm{d}}$ & $4.77 \pm 0.57^{\mathrm{e}}$ \\
\hline $\mathrm{LaPO}$ & MLL & $0.23 \pm 0.28^{\mathrm{a}}$ & $0.88 \pm 0.13^{\mathrm{a}}$ & $1.21 \pm 0.10^{\mathrm{b}}$ & $2.63 \pm 0.47^{\mathrm{c}}$ & $1.33 \pm 0.01^{\mathrm{c}}$ \\
\hline \multicolumn{7}{|l|}{$70: 30$} \\
\hline $\mathrm{LaLaO}$ & MML & $0.90 \pm 0.14^{\mathrm{a}}$ & $2.24 \pm 0.06^{\mathrm{b}}$ & $3.12 \pm 0.03^{\mathrm{c}}$ & $5.13 \pm 0.04^{\mathrm{d}}$ & $5.78 \pm 0.11^{\mathrm{e}}$ \\
\hline LaMO & MML & $0.34 \pm 0.06^{\mathrm{a}}$ & $0.74 \pm 0.06^{\mathrm{b}}$ & $1.17 \pm 0.10^{\mathrm{c}}$ & $2.68 \pm 0.11^{\mathrm{d}}$ & $2.93 \pm 0.04^{\mathrm{d}}$ \\
\hline LaPM & MLM & $1.41 \pm 0.01^{\mathrm{a}}$ & $1.22 \pm 0.03^{\mathrm{a}}$ & $1.25 \pm 0.07^{\mathrm{d}}$ & $2.83 \pm 0.04^{\mathrm{b}}$ & $2.58 \pm 0.11^{\mathrm{b}}$ \\
\hline $\mathrm{LaOO}$ & MLL & $0.00 \pm 0.00^{\mathrm{a}}$ & $1.15 \pm 0.07^{\mathrm{b}}$ & $1.96 \pm 0.08^{\mathrm{c}}$ & $4.51 \pm 0.01^{\mathrm{d}}$ & $5.43 \pm 0.04^{\mathrm{e}}$ \\
\hline $\mathrm{LaPO}$ & MLL & $0.12 \pm 0.07^{\mathrm{a}}$ & $0.64 \pm 0.06^{\mathrm{b}}$ & $0.94 \pm 0.06^{\mathrm{b}}$ & $2.49 \pm 0.13^{\mathrm{c}}$ & $1.40 \pm 0.14^{\mathrm{c}}$ \\
\hline
\end{tabular}

Means for the determined values in the same row followed by the same superscript letter are not significantly different ( $p>0.05$ ). Abbreviations: M: myristic acid; P: palmitic acid; S: stearic acid; O: oleic acid; L: linoleic acid; C: capric acid; La: lauric acid.

produced after the refining, bleaching and deodorizing (RBD) procedure with heating is applied especially during the deodorization process between 204 and $245^{\circ} \mathrm{C}$. However, VCO, known as a functional oil or mineral oil was produced in mild conditions (Chen et al., 2007) in order to maintain the bioactive compounds. As indicated by khoramnia et al. (2011) and Ebrahimpour et al. (2011), the mineral contents of the cultures play an essential role in the function of lipases.

Generally, as indicated by Ribeiro et al. (2009), the increased U2S content in the $\mathrm{MoO} / \mathrm{PO}$ and $\mathrm{MoO} / \mathrm{VCO}$ blends produced by enzymatic interesterification lead to greater potential for applying these interesterified blends in foods. S2U TAGs are associated with enhanced technological functionality and improved sensorial properties while S3 TAGs are responsible for the structure of the fat (Rodrigues and Gioielli, 2003). In addition, the contribution of oleic acid from $\mathrm{MoO}$ into the interesterified blends made them a potential candidate to be used as frying oils. As demonstrated by Abdulkarim et al. (2007a), MoO revealed great resistance during the frying procedure due to its high oleic acid content. Therefore, it could be proposed that the frying quality of PO enhanced after IE with $\mathrm{MoO}$ due to a lower degree of saturation and higher resistance. It could be also indicated that interesterified
$\mathrm{MoO} / \mathrm{VCO}$ fryng quality improved due to the MLCT generation and oleic acid contribution as the original VCO is not suitable for frying due to the high médium chain fatty acids and foam formation (Lee et al., 2012).

\subsection{Effect of enzymatic interesterification on DSC thermograms}

Figures 2 and 3 show the melting and crystallization thermograms of the interesterified $\mathrm{MoO} /$ $\mathrm{PO}$ and $\mathrm{MoO} / \mathrm{VCO}$ blends, respectively. Generally, by increasing the proportion of $\mathrm{MoO}$, the melting profile of both IE blends is supposed to shift towards lower temperature regions indicating a generation of TAGs with lower melting points. However, as a result of the S3 increase in interesterified $\mathrm{MoO} / \mathrm{PO}$, the corresponding melting profile shifted towards higher temperature regions (Table 1).

In $\mathrm{MoO} / \mathrm{PO}$ interesterified blends, by increasing $\mathrm{MoO}$, a new peak (peak 3) was generated in 50:50 w/w and 70:30 w/w. As IE progressed, the enthalpy of the major peak 1 in MoO/PO 30:70 and 50:50 w/w blends increased, while peak 2 decreased followed by an overlapping with peak 1 . This indicates a reduction in TAGs as represented by peak 2 and a possible formation of more TAGs, which was 
a)

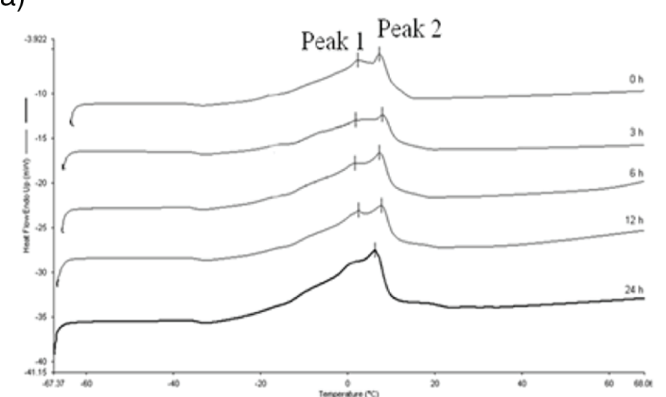

b)

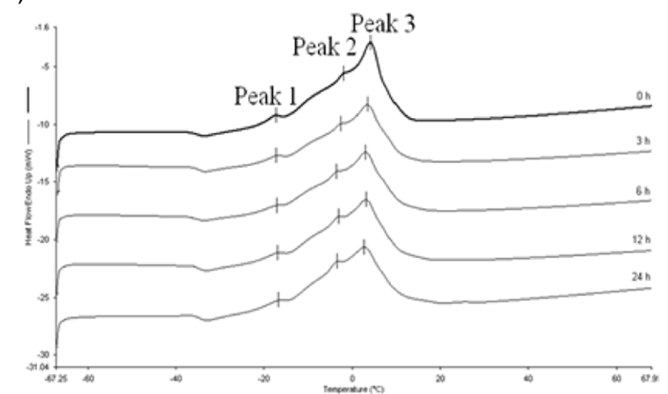

c)

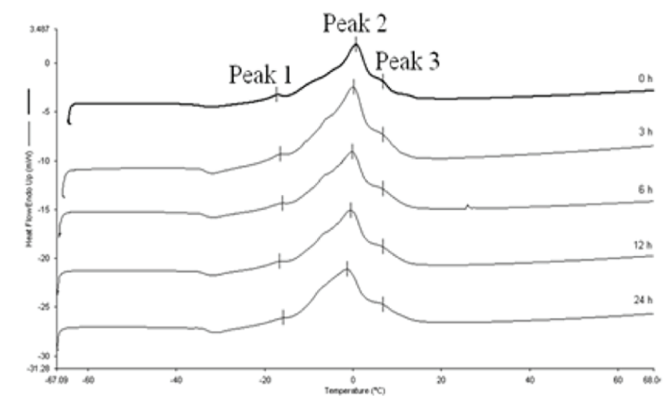

d)

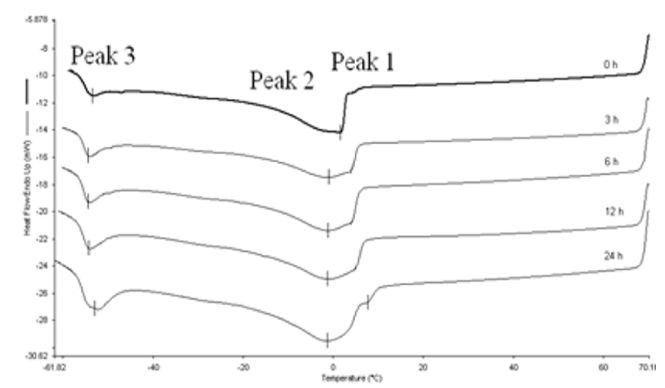

e)

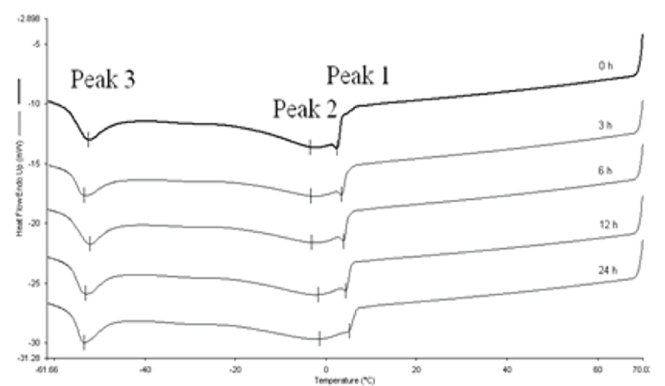

f)

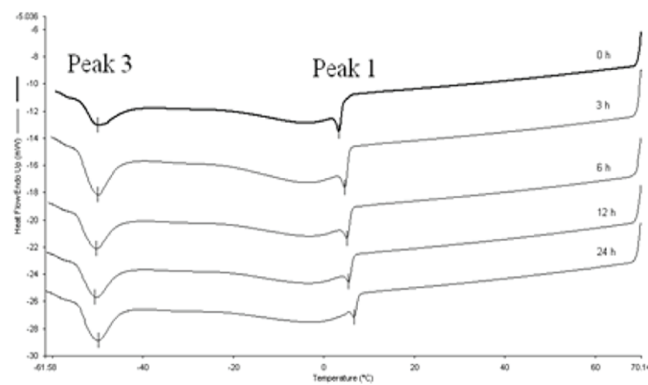

FIGURE 2. Melting and crystallization profile of Lipozyme RMIM interesterified MoO/PO blends. Melting profiles for (a) 30:70 w/w (b) $50: 50 \mathrm{w} / \mathrm{w}$ (c) 70:30 w/w blending ratios and crystallization profiles for (d) 30:70 w/w (e) 50:50 w/w (f) 70:30 w/w blending ratios.

represented by peak 1 . However, in the $\mathrm{MoO} / \mathrm{PO}$ $70: 30$ blend, peak 1 gradually disappeared and the TAG represented by peak 2 became the dominant TAG. This is as expected as the blend contained a higher quantity of $\mathrm{MoO}$ which, when compared to PO, has a higher degree of unsaturated FA. These findings indicated that the blends were composed mainly of low melting TAGs, and the TAGs representing peak 3 were contributed by $\mathrm{MoO}$. This result is expected as the main FA of the blends is oleic acid and $\mathrm{OOO}$ is the main TAG. da Silva et al. (2010) reported that triunsaturated TAGs have melting points from $-14{ }^{\circ} \mathrm{C}$ to $1{ }^{\circ} \mathrm{C}$, and triolein has a melting point of $-4{ }^{\circ} \mathrm{C}$ (Hynes, 2010).

In the crystallization thermograms of unreacted $\mathrm{MoO} / \mathrm{PO}$ blends (Figure 2), three crystallization peaks (peaks 1, 2 and 3) were observed. However, peak 2 gradually disappeared when the proportion of MoO was increased over the time of IE. Concurrently, it was observed that the size of peak 3 increased and as IE progressed it shifted to a lower temperature region, indicating the synthesis of lower melting TAGs. From the cooling thermograms of $\mathrm{MoO} / \mathrm{PO} 70: 30$ blends, two obvious crystallization peaks were observed: TAGs representing Peak 1, which crystallized at $3.36^{\circ} \mathrm{C}$, and those representing Peak 2, which crystallized at $-49.97^{\circ} \mathrm{C}$. After $24 \mathrm{~h}$ IE, the TAGs in Peak 1 crystallized at a higher temperature $\left(6.69{ }^{\circ} \mathrm{C}\right)$, whereas there was little change in the peak temperature for the TAGs represented by Peak 2 .

The above results show that the IE of different blends of $\mathrm{MoO} / \mathrm{PO}$ would produce TAG species with wide ranging crystallization and melting temperatures. The resulting blends were found to have higher end set temperatures than the melting temperatures before IE. However, the melting temperatures were still lower than the original MoO, except for the blends containing 30\% MoO which melted at $22.97{ }^{\circ} \mathrm{C}$. Abdulkarim et al. (2007b) reported 

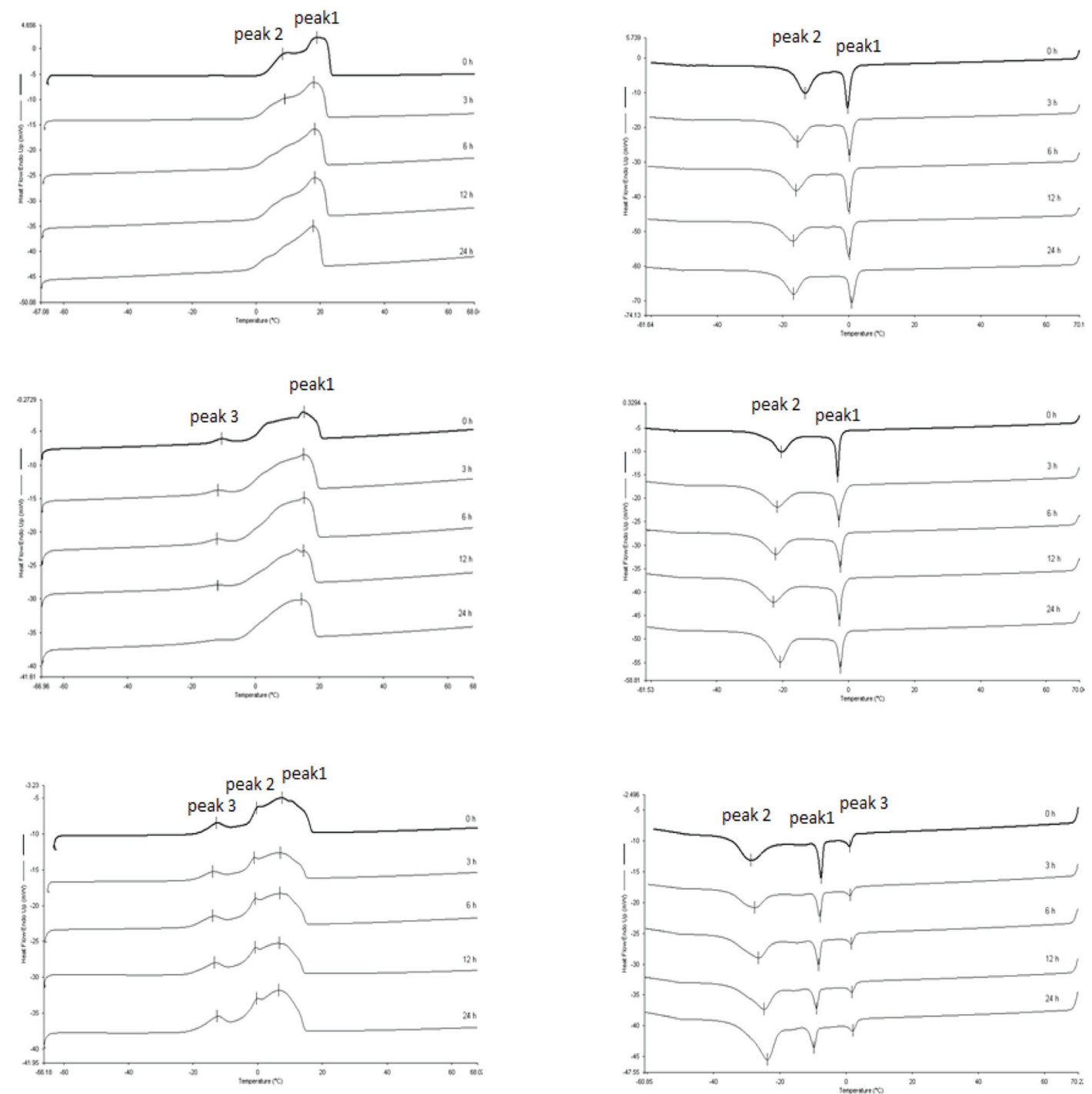

FIGURE 3. Melting and crystallization profiles of Lipozyme RMIM interesterified MoO/VCO blends. Melting profiles for (a) 30:70 w/w (b) 50:50 w/w (c) 70:30 w/w blending ratios and crystallization profiles for (d) 30:70 w/w (e) 50:50 w/w (f) 70:30 w/w blending ratios.

the increase in melting temperature from $18.9^{\circ} \mathrm{C}$ (control) to $20.5^{\circ} \mathrm{C}$ after $24 \mathrm{~h}$ self-IE of $\mathrm{MoO}$ using Lipozyme IM 60. This was reflected in the crystallization temperature increase from $1.6^{\circ} \mathrm{C}$ to $12.9^{\circ} \mathrm{C}$. Long et al. (2003) reported that the slip melting point of palm olein/flaxseed oil blends $(90: 10 \mathrm{w} / \mathrm{w})$ also increased from $14.1^{\circ} \mathrm{C}$ to $19.9^{\circ} \mathrm{C}$ after $6 \mathrm{~h}$ IE using Lipozyme IM, indicating that the synthesis of higher melting point TAGs took place during the rearrangement of the FA moiety.

The results for the IE of the MoO/VCO blends (Figure 3) provide several important observations concerning the melting and crystallization profiles. In the melting profile of the 30:70 blend, a low melting Peak 2 represented unstable TAG crystals of low melting points that melted earlier and this peak then became broader and finally overlapped with the major TAG peak (peak 1) after 6-24 h of IE, resulting in peak 1 shifting to a lower melting region indicating the reduction of high melting TAGs due to oleic acid incorporation and a higher degree of unsaturation. The melting thermogram of the interesterified $\mathrm{MoO} / \mathrm{VCO} 70: 30$ blend (Figure 3) displayed a welldefined peak which is related to the low, medium and high melting points of TAGs which melt in a wide temperature range. The major melting peak (peak 1) of $0 \mathrm{~h}$ blend occurred at $7.47^{\circ} \mathrm{C}$ with shoulder peaks (peak 2) at $-0.32{ }^{\circ} \mathrm{C}$ and a minor peak (peak 3) at $-12.87^{\circ} \mathrm{C}$. After the IE of MoO/VCO 70:30 blend, the minor and major melting peaks shifted towards the low temperature region, resulting in a reduction in the melting temperature of the interesterified blend. This indicated that the rearrangement of FAs responsible for these peaks leading to the formation of lower melting TAGs after IE were most likely to be influenced by unsaturated FA (oleic acid 
incorporation) from $\mathrm{MoO}$. For blends with lower proportions of $\mathrm{MoO}$, the thermal properties of the interesterified oil revealed an influence of saturated FA rich in VCO.

Generally, in the $\mathrm{MoO} / \mathrm{VCO}$ crystallization thermogram, the major crystallization peak (peak 1) was observed with a minor peak (peak B) for the 30:70 blend ratio. During the IE of MoO/VCO 30:70, the major crystallization peak decreased and the minor peak increased. Both results from the melting and crystallization thermograms indicate that a softer mixture has been produced.

\subsection{Effect of enzymatic interesterification on solid fat content}

The solid fat content (SFC) profile as a function of temperature for the $\mathrm{MoO} / \mathrm{PO}$ and $\mathrm{MoO} / \mathrm{VCO}$ blends, interesterified at various times and ratios, is shown in Table 3. The SFC of the blends at $0{ }^{\circ} \mathrm{C}$ is related to the degree of saturation: the higher the amount of $\mathrm{MoO}$ in the blends, the lower the SFC is at $0{ }^{\circ} \mathrm{C}$. Likewise, the greater the quantity of either PO or VCO in the blends, the higher the SFC is at $0{ }^{\circ} \mathrm{C}$. The obtained result indicates that unlike $\mathrm{MoO} / \mathrm{VCO}$, IE caused the formation of more saturated TAGs which then contributed to an increase in melting temperature in the $\mathrm{MoO} / \mathrm{PO}$ blends which is in accordance with the results obtained in previous sections. In this agreement, Long et al. (2003) and Abdulkarim et al. (2007b) demonstrated elevated SFC after IE indicating the ability of the enzyme to form higher-melting TAGs.

The findings show that for each $\mathrm{MoO} / \mathrm{PO}$ blend ratio, the temperature at which SFC is zero increased after IE, compared to the control $(0 \mathrm{~h})$. However, it still remained below ambient temperature $\left(25-27^{\circ} \mathrm{C}\right)$ or body temperature $\left(35-37^{\circ} \mathrm{C}\right)$. After $24 \mathrm{~h} \mathrm{IE}$, the $\mathrm{SFC} \%$ of all $\mathrm{MoO} / \mathrm{PO}$ ratios increased where 30:70 w/w blend revealed more obvious changes compared to other ratios. The major difference was observed at $10{ }^{\circ} \mathrm{C}$ and $15{ }^{\circ} \mathrm{C}$ with SFC values of $4.6 \%$ and $0 \%$ in unreacted $(0 \mathrm{~h}) \mathrm{MoO} / \mathrm{PO} 30: 70 \mathrm{w} / \mathrm{w}$ blend which increased to $11.1 \%$ and $6 \%$ after $24 \mathrm{~h} \mathrm{IE}$, respectively. As stated in the TAG section, due to the TAG rearrangements after the IE of $\mathrm{MoO} / \mathrm{PO}$, the level of S3 (MML) increased by up to $2.55 \%$ in the $30: 70$ blend. It could be concluded that $2.55 \%$ of $\mathrm{S} 3$ enhancement brings about $6.5 \%$ and $6 \%$ more $\mathrm{SFC} \%$ in 10 and $15{ }^{\circ} \mathrm{C}$, respectively. According to Rodrigues and Gioielli (2003), S3 TAGs are responsible for the structure of fatty foods.

Consequently, interesterified $\mathrm{MoO} / \mathrm{PO}$ revealed a harder structured fat blend produced from two liquid oils due to the function of Lipozyme RMIM. Changes in the amount of TAG species after IE are normally accompanied by a change in the SFC, depending on the type of TAG formed (Debnath et al., 2011; Koh et al., 2010).
In interesterified $\mathrm{MoO} / \mathrm{VCO}$ blends the level of $\mathrm{S} 3$ decreased following the increase in the U2S level resulting in the production of softer fat. Soares et al. (2012) also reported SFC reduction in a coconut oil-canola oil interesterified blend. At $20^{\circ} \mathrm{C}$, the interesterified $\mathrm{MoO} / \mathrm{VCO}$ 50:50 blend showed $0 \%$ SFC while it was higher for the 30:70 blend and lower for 70:30 due to the difference in the oleic acid incorporation associated with the $\mathrm{MoO}$ level. At low temperatures $\left(4-10{ }^{\circ} \mathrm{C}\right)$, where SFC gives an indication of the fat's spreadability, VCO originally do not offer satisfactory characteristics with SFC values of $89.8 \%$. Ribeiro et al. (2009), Wassell and Young (2007) and Lida and Ali (1998) demonstrated that for spreadability at refrigeration temperatures, the SFC should not exceed $32 \%$ at $10{ }^{\circ} \mathrm{C}$ in order to meet the minimum plasticity requirement. The binary blends of 70:30 w/w MoO/VCO can be regarded as offering good spreadability at low temperatures $\left(10^{\circ} \mathrm{C}\right)$ with $\mathrm{SFC}$ values of 23.1 to $11.2 \%$ after 0 to $24 \mathrm{~h} \mathrm{IE}$, respectively. The product's stability and its resistance to oiling-out could be characterized in fats with a minimum of $10 \% \mathrm{SFC}$ between 20 and $22^{\circ} \mathrm{C}$ (Lida et al., 1998; Wassell and Young, 2007). The unreacted binary blend of $\mathrm{MoO} / \mathrm{VCO}$ $30: 70 \mathrm{w} / \mathrm{w}$ with $20.1 \%$ and $10.9 \% \mathrm{SFC}$ at 20 and $22{ }^{\circ} \mathrm{C}$, respectively and the interesterified blend after $6 \mathrm{~h}$ with $11.3 \% \mathrm{SFC}$ fall within this group of fats.

Blends with zero SFC at $25^{\circ} \mathrm{C}$ including $\mathrm{MoO} / \mathrm{PO}$ 50:50 and 70:30 w/w after $12 \mathrm{~h}$ IE and MoO/VCO 30:70 are suitable for incorporation into the fat phase in ice-cream formulations as demonstrated by Liew et al. (2001). In addition, the MoO/VCO interesterified blends with elevated levels of MLCT may improve the quality of pastries as Ariffin et al. (2010) reported that cookies made from mediumand long-chain triacylglycerol-enriched margarines have good texture and sensory perception as well as excellent nutritional benefits.

\section{CONCLUSIONS}

This study has shown that enzymatic interesterification with $\mathrm{MoO}$ an effective way to modify the physical and chemical properties of PO and VCO. With regards to thermal properties, the broadening and shifting of Peaks were clearly seen, indicating the formation of TAG species with a wider melting range that have clearly affected the SFC of the interesterified blends. Interesterification of $\mathrm{MoO} / \mathrm{PO}$ blends caused an increase in the concentration of high melting TAGs, thus increasing the product's melting temperature and $\mathrm{SFC} \%$ at higher temperatures. All interesterified $\mathrm{MoO} / \mathrm{VCO}$ blends melted at lower temperatures which allowed them to remain liquid at ambient temperature while improving their spreadability and plasticity at refrigerated temperatures. Healthier frying blends and ice-cream fat bases were produced from $\mathrm{MoO}$ interesterified 


\begin{tabular}{|c|c|c|c|c|c|c|c|c|c|c|c|c|c|c|c|c|c|c|c|c|c|}
\hline \multirow{3}{*}{$\begin{array}{l}\mathrm{MoO} / \mathrm{PO} \\
\text { blends (w/w) }\end{array}$} & \multicolumn{10}{|c|}{ Solid fat content (\%) } & \multirow{3}{*}{$\begin{array}{c}\mathrm{MoO} / \mathrm{VCO} \\
\text { blends (w/w) }\end{array}$} & \multicolumn{10}{|c|}{ Solid fat content $(\%)$} \\
\hline & \multicolumn{10}{|c|}{ Temperature $\left({ }^{\circ} \mathrm{C}\right)$} & & \multicolumn{10}{|c|}{ Temperature $\left({ }^{\circ} \mathbf{C}\right)$} \\
\hline & $\mathbf{0}$ & 2 & 5 & 7 & 10 & 15 & 20 & 25 & 30 & 35 & & $\mathbf{0}$ & 5 & 10 & 12 & 15 & 17 & 20 & 22 & 25 & 30 \\
\hline $\mathrm{MoO}$ & 34.8 & 27.0 & 15.4 & 10.8 & 4.0 & 0.9 & 0.1 & 0.0 & - & - & $\mathrm{MoO}$ & 34.8 & 15.4 & 4.0 & 2.8 & 0.9 & 0.6 & 0.1 & 0.0 & - & - \\
\hline $\mathrm{PO}$ & 60.5 & 50.3 & 34.9 & 24.1 & 8.0 & 0.5 & 0.0 & - & - & - & VCO & 94.9 & 91.9 & 89.8 & 84.6 & 76.9 & 66.5 & 50.8 & 32.0 & 3.7 & 0.0 \\
\hline $30: 70$ & & & & & & & & & & & $30: 70$ & & & & & & & & & & \\
\hline 0 & 53.5 & 43.4 & 28.3 & 17.8 & 4.6 & 0.0 & - & - & - & - & 0 & 100.0 & 96.1 & 77.1 & 68.3 & 54.1 & 40.5 & 20.1 & 10.9 & 0.0 & - \\
\hline 3 & 53.8 & 44.9 & 31.5 & 21.7 & 9.0 & 2.4 & 0.8 & 0.2 & 0.0 & - & 3 & 99.6 & 91.1 & 71.6 & 61.9 & 46.1 & 30.8 & 9.4 & 4.4 & 0.0 & - \\
\hline 6 & 53.0 & 44.1 & 30.7 & 20.8 & 8.1 & 2.3 & 0.7 & 0.2 & 0.0 & - & 6 & 99.7 & 92.9 & 74.2 & 64.4 & 48.7 & 33.2 & 11.3 & 5.4 & 0.0 & - \\
\hline 12 & 55.9 & 46.7 & 32.9 & 23.0 & 10.1 & 3.8 & 1.1 & 0.4 & 0.0 & - & 12 & 99.5 & 91.2 & 72.3 & 61.7 & 44.7 & 28.4 & 6.4 & 2.9 & 0.0 & - \\
\hline 24 & 52.6 & 43.5 & 30.1 & 21.6 & 11.1 & 6.0 & 2.6 & 1.0 & 0.2 & 0.0 & 24 & 98.9 & 88.6 & 69.3 & 57.7 & 39.6 & 23.1 & 1.6 & 0.6 & 0.0 & - \\
\hline 50:50 & & & & & & & & & & & $50: 50$ & & & & & & & & & & \\
\hline 0 & 47.0 & 35.5 & 19.7 & 11.8 & 3.6 & 0.5 & 0.0 & - & - & - & 0 & 90.3 & 73.9 & 51.0 & 40.3 & 24.5 & 14.5 & 0.0 & - & - & - \\
\hline 3 & 45.9 & 34.8 & 19.4 & 11.9 & 4.2 & 0.8 & 0.0 & - & - & - & 3 & 90.3 & 74.0 & 49.5 & 37.5 & 20.6 & 12.1 & 0.0 & - & - & - \\
\hline 6 & 45.7 & 34.3 & 18.7 & 11.5 & 4.3 & 0.7 & 0.0 & - & - & - & 6 & 91.1 & 76.4 & 51.0 & 38.6 & 21.1 & 11.7 & 0.0 & - & - & - \\
\hline 12 & 45.3 & 34.4 & 19.3 & 12.3 & 5.1 & 1.3 & 0.3 & 0.0 & - & - & 12 & 90.6 & 75.0 & 48.7 & 35.1 & 16.6 & 8.8 & 0.0 & - & - & - \\
\hline 24 & 45.2 & 34.7 & 20.4 & 13.7 & 6.9 & 2.5 & 0.7 & 0.2 & 0.0 & - & 24 & 91.6 & 75.0 & 48.3 & 24.7 & 16.5 & 8.7 & 0.0 & - & - & - \\
\hline $70: 30$ & & & & & & & & & & & $70: 30$ & & & & & & & & & & \\
\hline 0 & 39.0 & 28.1 & 13.5 & 8.0 & 3.4 & 0.5 & 0.0 & - & - & - & 0 & 72.8 & 49.5 & 23.1 & 13.7 & 2.5 & 0.9 & 0.0 & - & - & - \\
\hline 3 & 34.7 & 25.2 & 12.5 & 7.2 & 2.4 & 0.2 & 0.0 & - & - & - & 3 & 64.0 & 40.2 & 14.5 & 7.1 & 0.0 & - & - & - & - & - \\
\hline 6 & 34.5 & 25.8 & 13.9 & 8.7 & 3.6 & 0.6 & 0.0 & - & - & - & 6 & 63.5 & 39.9 & 14.1 & 7.8 & 0.0 & - & - & - & - & - \\
\hline 12 & 33.6 & 25.2 & 13.8 & 8.7 & 3.6 & 0.7 & 0.1 & 0.0 & - & - & 12 & 62.1 & 38.5 & 12.2 & 6.7 & 0.0 & - & - & - & - & - \\
\hline 24 & 32.0 & 24.8 & 14.8 & 10.1 & 5.0 & 1.4 & 0.4 & 0.0 & - & - & 24 & 60.6 & 36.7 & 11.2 & 6.2 & 0.0 & - & - & - & - & - \\
\hline
\end{tabular}


with PO and VCO using the Lipozyme RMIM. The findings indicate that the enzymatic IE of $\mathrm{MoO}$ with PO and VCO would enable the initial properties of the oils to be modified or altered and provide functional and nutritional attributes for use in various food applications, increasing the possibilities for commercial use of these oils.

\section{ACKNOWLEDGMENTS}

This study was financially supported by Universiti Putra Malaysia (UPM), research grant no. 02-01-04-SF0395.

\section{REFERENCES}

Abdulkarim SM, Long K, Lai OM, Muhammad, SKS, Ghazali HM. 2005. Some physico-chemical properties of Moringa oleifera seed oil extracted using solvent and aqueous enzymatic methods. Food Chem. 93, 253-263. http://dx.doi.org/ 10.1016/j.foodchem.2004.09.023.

Abdulkarim SM, Long K, Lai OM, Muhammad SKS, Ghazali, HM. 2007a. Frying quality and stability of high-oleic Moringa oleifera seed oil in comparison with other vegetable oils. Food Chem. 105, 1382-1389. http://dx.doi.org/ 10.1016/j.foodchem.2007.05.013.

Abdulkarim SM, Lai OM, Muhammad SKS, Long K, Ghazali, HM. 2007b. Oleic acid enhancement of Moringa oleifera seed oil by enzymatic transesterification and fractionation. Asia Food J. 14, 91-102.

Adhikari P, Zhu XM, Gautam A, Shin JA, Hu JN, Lee JH, Lee KT. 2010. Scaled-up production of zero-trans margarine fat using pine nut oil and palm stearin. Food Chem. 119, 1332-1338. http://dx.doi.org/10.1016/j.foodchem.2009.09.009.

AOAC (Association of Official Analytical Chemists). 1984. Methods of Analysis of the Association of Official Analytical Chemists. Washington, D.C.

Arifin N, Peng KS, Long K, Ping TC, Affandi Yusoff MS, Nor Aini I, Ming LO. 2010. Relationship between textural properties and sensory qualities of cookies made from mediumand long-chain triacylglycerol-enriched margarines. J. Sci. Food Agric. 90, 943-948.

Bansal G, Zhou W, Barlow PJ, Joshi PS, Lo HL, Chung YK. 2010. Review of rapid tests available for measuring the quality changes in frying oils and comparison with standard methods. Crit. Rev. Food Sci. Nutr. 50, 503-514. http:// dx.doi.org/10.1080/10408390802544611.

Bawalan DD, Chapman KR. 2006. Virgin coconut oil: Production manual for macro and village scale processing. In FAO (Ed.). Bangkok: Thamada Press.

Carluccio MA, Massaro M, Scoditti E, De Caterina, R. 2007. Vasculoprotective potential of olive oil components. Mol. Nutr. Food Res. 51, 1225-1234. http://dx.doi.org/10.1002/ mnfr.200600305.

Chen CW, Chong CL, Ghazali HM, Lai OM. 2007. Interpretation of triacylglycerol profiles of palm oil, palm kernel oil and their binary blends. Food Chem. 100, 178-191. http://dx.doi. org/10.1016/j.foodchem.2005.09.044

da Silva RC, Soares DF, Lourenço MB, Soares FASM, da Silva KG, Gonçalves MIA, Gioielli LA. 2010. Structured lipids obtained by chemical interesterification of olive oil and palm stearin. LWT - Food Sci. Technol. 43, 752-758.

Debnath S, Ravi R, Lokesh BR. 2011. Optimisation of lipasecatalysed interesterification reaction for modulating rheological and heat transfer properties of frying oil. Food Chem. 129, 1444-1452. http://dx.doi.org/10.1016/j. foodchem.2011.05.103

Ebrahimpour A, Rahman RN, Basri M, Salleh AB. 2011. High level expression and characterization of a novel thermostable, organic solvent tolerant, 1,3-regioselective lipase from Geobacillus sp. strain ARM. Bioresour Technol. 102, 6972-6981. http://dx.doi.org/10.1016/j.biortech.2011.03.083.
Fomuso L, Akoh C. 1998. Structured lipids: Lipase-catalyzed interesterification of tricaproin and trilinolein. $J$. Am. Oil Chem. Soc. 75, 405-410. http://dx.doi.org/10.1007/ s11746-998-0059-y.

Gerhard G, Ahmann A, Meeuws K, McMurry MP, Duell PB, Connor WE. 2004. Effects of a low-fat diet compared with those of a high-monounsaturated fat diet on body weight, plasma lipids and lipoproteins, and glycemic control in type 2 diabetes. Am. J. Clin. Nutr. 80, 668-673.

Ghazali HM, Hamidah S, Che Man YB. 1995a. Enzymatic transesterification of palm olein with nonspecific and 1,3-specific lipases. J. Am. Oil Chem. Soc. 72, 633-639. http://dx.doi.org/10.1007/BF02635647.

Hynes WM. 2010. CRC Handbook of chemistry and physics. Boca Raton, Florida: CRC Press Inc.

Khatoon S, Reddy SRY. 2005. Plastic fats with zero trans fatty acids by interesterification of mango, mahua and palm oils. Europ. J. Lipid Sci. Technol. 107, 786-791. http:// dx.doi.org/10.1002/ejlt.200501210.

Khoramnia A, Ebrahimpour A, Beh BK, Lai OM. 2011. Production of a solvent, detergent, and thermotolerant lipase by a newly isolated Acinetobacter sp. in submerged and solid-state fermentations. J. Biomed. Biotechnol. 2011, 702179. http://dx.doi.org/10.1155/2011/702179.

Koh SP, Tan CP, Lai OM, Arifin N, Yusoff MSA, Long K. 2010. Enzymatic Synthesis of Medium- and Long-Chain Triacylglycerols (MLCT): Optimization of Process Parameters Using Response Surface Methodology. Food Biop. Technol. 3, 288-299. http://dx.doi.org/10.1007/s11947008-0073-y.

Lee YY, Tang TK, Lai OM. 2012. Health benefits, enzymatic production, and application of medium- and long-chain triacylglycerol (MLCT) in food industries: a review. $J$. Food Sci. 77, 137-144. http://dx.doi.org/10.1111/j.17503841.2012.02793.x

Lida H, Ali AR. 1998. Physico-chemical characteristics of palmbased oil blends for the production of reduced fat spreads. J. Am. Oil Chem. Soc. 75, 1625-1631. http://dx.doi.org/ 10.1007/s11746-998-0103-y.

Liew MYB, Ghazali HM, Long K, Lai OM, Yazid AM. 2001. Physical and chemical properties of palm kernel olein-anhydrous milk fat mixtures transesterified using mycelium-bound lipase from Rhizomucor miehei. Food Chem. 72, 447-454. http://dx.doi.org/10.1016/S0308-8146 (00)00255-7.

Long K, Zubir I, Hussin AB, Idris N, Ghazali HM, Lai OM. 2003. Effect of enzymatic transesterification with flaxseed oil on the high-melting glycerides of palm stearin and palm olein. J. Am. Oil Chem. Soc. 80, 133-137. http://dx.doi. org/10.1007/s11746-003-0665-5.

Marina AM, Che Man YB, Nazimah SAH, Amin I. 2009a. Chemical Properties of Virgin Coconut Oil. J. Am. Oil Chem. Soc. 86, 301-307. http://dx.doi.org/10.1007/ s11746-009-1351-1

Marina AM, Che Man YB, Amin I. 2009b. Virgin coconut oil: emerging functional food oil. Trends Food Sci. Technol. 20, 481-487. http://dx.doi.org/10.1016/j.tifs.2009.06.003.

Matsuo T, Matsuo M, Kasai M, Takeuchi H. 2001. Effects of a liquid diet supplement containing structured medium- and long-chain triacylglycerols on bodyfat accumulation in healthy young subjects. Asia Pac. J. Clin. Nutr. 10, 46-50. http://dx.doi.org/10.1046/j.1440-6047.2001.00196.x.

O'Brien RD. 2003. Fats and oils: Formulating and processing for applications. New York: Springer. http://dx.doi. org/10.1201/9780203483664

Palla CA, Pacheco C, Carrín ME. 2012. Production of structured lipids by acidolysis with immobilized Rhizomucor miehei lipases: Selection of suitable reaction. J. Mol. Cat. B: Enz. 76, 106-115. http://dx.doi.org/10.1016/j.molcatb. 2011.11.022.

Pérez CMC, Márquez-Ruiz G, Ruiz-Méndez MV, Dobarganes MC. 1991. Lipid Changes during Frying of Frozen Prefried Foods. J. Food Sci. 56, 1644-1647. http://dx.doi. org/10.1111/j.1365-2621.1991.tb08661.x.

Ramachandran C, Peter KV, Gopalakrishnan PK. 1980. Drumstick (Moringa oleifera): A multipurpose Indian 
vegetable. Econ. Bot. 34, 276-283. http://dx.doi.org/ 10.1007/BF02858648.

Ribeiro APB, Grimaldi R, Gioielli LA, Gonçalves LAG. 2009. Zero trans fats from soybean oil and fully hydrogenated soybean oil: Physico-chemical properties and food applications. Food Res. Int. 42. 401-410. http://dx.doi. org/10.1016/j.foodres.2009.01.012.

Riveros CG, Mestrallet MG, Gayol MF, Quiroga PR, Nepote V, Grosso NR. 2010. Effect of storage on chemical and sensory profiles of peanut pastes prepared with high-oleic and normal peanuts. J. Sci. Food Agric. 90, 2694-2699. http:// dx.doi.org/10.1002/jsfa.4142.

Soares FASDM, da Silva RC, Hazzan M, Capacla IR, Viccola ER, Maruyama JM, Gioielli LA. 2012. Chemical Interesterification of Blends of Palm Stearin, Coconut Oil, and Canola Oil: Physicochemical Properties. J. Agric. Food Chem. 60, 1461-1469. http://dx.doi.org/10.1021/jf204111t.
Tsaknis J. Lalas S. 2002. Stability During Frying of Moringa oleifera Seed Oil Variety "Periyakulam 1". J. Food Comp. Anal. 15, 79-101. http://dx.doi.org/10.1006/jfca. 2001.1043 .

Utsugi A, Kanda A, Hara S. 2009. Lipase specificity in the transacylation of triacylglycerin. J. Oleo Sci. 58, 123-132. http://dx.doi.org/10.5650/jos.58.123.

Warner K, Knowlton S. 1997. Frying quality and oxidative stability of high-oleic corn oils. J. Am. Oil Chem. Soc, 74, 1317-1322. http://dx.doi.org/10.1007/s11746-997-0063-7.

Wassell P, Young NWG. 2007. Food applications of trans fatty acid substitutes. Int. J. Food Sci. Technol. 42, 503-517. http://dx.doi.org/10.1111/j.1365-2621.2007.01571.x.

Xuebing X, Casimir CA. 2002. Enzymatic Production of Betapol and other specialty fats. Lipid Biotechnol: CRC Press. 